\title{
Analysis And Selection Of Logistics Model---Take The Example Of Nicks Company
}

\author{
Guogang $\mathrm{Li}^{1, \mathrm{a}}$, Jiaojiao $\mathrm{Qi}{ }^{1, \mathrm{~b}}$ \\ ${ }^{1}$ School of Tianjin University of technology, Tianjin 300384, China; \\ ${ }^{1}$ School of Tianjin University of technology, Tianjin 300384, China; \\ a980776046@qq.com, ${ }^{b} 13342063029 @ 163 . c o m$,
}

Keywords:logistics model analytic hierarchy process logistics demand

\begin{abstract}
Chinese logistics industry has started late, the overall management model is still in constant exploration. At present,our country enterprise the most widely used is the traditional logistics mode. To solve the problem of low efficiency and the company to keep up with the demand of modern logistics, this article take an example of the Tianjin Nicks company, using the analytic hierarchy process, the depth of its logistics whether the model can effectively improve the place, and showing the feasible suggestions and countermeasures.
\end{abstract}

\section{Introduction}

With the rapid development of information technology, it has gradually form that the trend of economic globalization, the world has become a "global village", the world is organized into the global production network. In modern production, enterprises want to through traditional methods such as reducing the use cost of materials and equipment to strengthen the production level through science and technology, it is not enough to achieve the enterprise economic goals. In this economic situation, there is no doubt that the modern logistics industry has become the most concern of profit growth for the enterprises. The logistics industry has become the economic benefits of enterprises third economic source, has tremendous economic benefits. The level of logistics management of an enterprise is directly related to the To production cost, so it can indirectly affect the economic benefits of the enterprises in the development, so that the business has become already under current economic environment the core market competition between enterprises. The industry with the economic level in China, improve the people's consumption capacity and obtain equal leap, therefore it also for the entire industry requires more management. The ways to promote the development of modern logistics, the development structure created by science, this is the one we are focused on a major issue. Because our country in the field of foreign industry in developed countries is still at the beginning that could grope stage, and then the inevitable, today's domestic user are quite traditional logistics model. Through empirical research status of Tianjin Flying Nicks company, in its analysis of the logistics mode whether can effectively enhance the place, and gives a specific optimization scheme. 


\section{Research status at home and abroad}

Through the review of the literature found abroad logistics industry has experienced decades of development. Firstly, the history of the development of logistics in the more distant, the theoretical study of logistics management system are more fully, so also put forward some of the policies and regulations of the logistics management, logistics business here to mature the United States cases, regulations promulgated by the United States on the logistics management of the main federal court according to the contract of carriage from the perspective of logistics management and logistics enterprises according to the market need to decide the logistics development strategy ", they found in the logistics logistics management through the study of these relatively mature countries management is not a specific professional department to operate[1]. Secondly, research on these policies and regulations can be found, so the logistics market in the United States and Japan are relatively mature countries in this area have not developed a specific enterprise logistics management policies and regulations, the logistics management is the main different some of the policies to guide its development. From the situation of China's logistics current situation, first of all, China's logistics production organization form is dispersed and inefficient. This shows China's logistics industry in the extensive mode of operation of the shortcomings [2,3]. Secondly, modern logistics industry has not broken the status of their closed, this is the situation of logistics enterprises in China the exchange opportunity is relatively small, and each acts in his own way of logistics management is the enterprise internal departments. In addition, China is still missing from the macro aspects of the development of the logistics industry is expounded in the theory research on logistics theory, many research results are still stuck in the address selection of logistics, logistics and transport storage and packaging. Such as no substantive development on the issue [4].

\section{Research on logistics model of Nicks company based on Analytic Hierarchy Process}

Using the analytic hierarchy process to carry on the empirical analysis -- the

initial proof. Table 1 for the initial matrix obtained by comparison of 22:

Table.1 Evaluation pairwise comparisons

\begin{tabular}{|c|c|c|c|c|}
\hline & $\begin{array}{c}\text { The } \\
\text { important of } \\
\text { logistics network }\end{array}$ & $\begin{array}{c}\text { Total } \\
\text { logistics cost }\end{array}$ & $\begin{array}{c}\text { Competitiveness } \\
\text { of logistics } \\
\text { management }\end{array}$ & $\begin{array}{c}\text { Market } \\
\text { flexibility } \\
\text { demand }\end{array}$ \\
\hline $\begin{array}{c}\text { Importance of logistics } \\
\text { network }\end{array}$ & 1 & 5 & 5 & 3 \\
\hline Total logistics cost & $1 / 5$ & 1 & 2 & 2 \\
\hline $\begin{array}{c}\text { Logistics management } \\
\text { competitiveness }\end{array}$ & $1 / 5$ & $1 / 2$ & 1 & 1 \\
\hline $\begin{array}{c}\text { Market flexibility } \\
\text { demand }\end{array}$ & $1 / 3$ & $1 / 2$ & 1 & 1 \\
\hline
\end{tabular}

Adjusted matrix. The adjusted matrix is shown in table 2: 
Table.2 Evaluation pairwise comparisons

\begin{tabular}{|c|c|c|c|c|c|}
\hline & $\begin{array}{c}\text { Importance of } \\
\text { logistics } \\
\text { network }\end{array}$ & $\begin{array}{c}\text { Total } \\
\text { logistics } \\
\text { cost }\end{array}$ & $\begin{array}{c}\text { Competitiveness } \\
\text { of logistics } \\
\text { management }\end{array}$ & $\begin{array}{c}\text { Market } \\
\text { flexibility } \\
\text { demand }\end{array}$ & weight \\
\hline $\begin{array}{c}\text { Importance of logistics } \\
\text { network }\end{array}$ & 1 & 5 & 5 & 3 & 0.569 \\
\hline Total logistics cost & $1 / 5$ & 1 & 2 & 2 & 0,192 \\
\hline $\begin{array}{c}\text { Logistics management } \\
\text { competitiveness }\end{array}$ & $1 / 5$ & $1 / 2$ & 1 & 1 & 0.110 \\
\hline $\begin{array}{c}\text { Market flexibility } \\
\text { demand }\end{array}$ & $1 / 3$ & $1 / 2$ & 1 & 1 & 0.129 \\
\hline
\end{tabular}

The arrangement of logistics model. The importance of logistics network hierarchy table, logistics total cost of logistics, and hierarchy of market demand and logistics mode respectively in the table 3,table4,table5 and table6. The result of table 3 suggest that through the consistency test. Likewise, in Table 4, Table 5 and table 6, through the consistency verification.

Table3 The importance of the logistics network

\begin{tabular}{|c|c|c|c|c|}
\hline & A & B & C & weight \\
\hline A & 1 & 5 & 3 & 0.656 \\
\hline B & $1 / 5$ & 1 & 1 & 0.158 \\
\hline C & $1 / 3$ & 1 & 1 & 0.187 \\
\hline
\end{tabular}

Table4 Total logistics costs

\begin{tabular}{|c|c|c|c|c|}
\hline & A & B & C & weight \\
\hline A & 1 & $1 / 3$ & $1 / 5$ & 0.101 \\
\hline B & 3 & 1 & 1 & 0.363 \\
\hline C & 5 & 2 & 1 & 0.537 \\
\hline
\end{tabular}

Table5 Competitiveness of Logistics Management

\begin{tabular}{|c|c|c|c|c|}
\hline & A & B & C & weight \\
\hline A & 1 & 2 & 2 & 0.467 \\
\hline B & $1 / 2$ & 1 & 1 & 0.233 \\
\hline C & $1 / 2$ & 2 & 1 & 0.300 \\
\hline
\end{tabular}

Table6 Total Sort logistics model level

\begin{tabular}{|c|c|c|c|c|c|}
\hline & $\begin{array}{c}\text { Importance of } \\
\text { logistics network }\end{array}$ & $\begin{array}{c}\text { Total } \\
\text { logistics cost }\end{array}$ & $\begin{array}{c}\text { Competitiveness of } \\
\text { logistics management }\end{array}$ & $\begin{array}{c}\text { Market flexibility } \\
\text { demand }\end{array}$ & weight \\
\hline A & 0.569 & 0.192 & 0.110 & 0.129 & \\
\hline B & 0.656 & 0.101 & 0.467 & 0.467 & 0.504 \\
\hline C & 0.158 & 0.363 & 0.233 & 0.233 & 0.215 \\
\hline
\end{tabular}

It can be seen that by using the AHP method, the influence of the four factors of the logistics mode of comparative analysis on the Fly logistics mode of Nicks enterprises, analysis results showed that the weight of Fly Nicks company's current 
logistics mode for three kinds of logistics mode is relatively low, so the company can consider the future Fly Nicks the current model to the development of self mode, if the company uses a Fly Nicks self logistics mode so more direct use of logistics assets in the future will be able to, give full play to their own logistics management functions that can supply certain protection. It is more important that the modernization of logistics Self model can satisfy the enterprise for the production and marketing integration process, it can not only meet the needs of some within the company, but also to further open the market[5]. Consider strengthening distribution network service performance can be Nicks enterprises in the later operation, by strengthening the construction of the logistics distribution center, in the operation process of logistics important continuous improvement the logistics service system, constantly expand the logistics service market, in order to enhance their competitiveness by improving the logistics service quality, which is more conducive to the long-term strategic development of the company [6, 7].

\section{Conclusion}

In the logistics system, the logistics model analysis and research on the optimization of logistics management system which plays a very important role. Whether the choice of logistics business development of a suitable logistics mode of an enterprise is very important. In this paper, through the study found that if you want to perfect the material flow theory and methods, so that enterprises in the the choice of logistics mode to make more scientific, accurate and comprehensive consideration, future research should pay attention to the following aspects:

(1) the uncertainty factors of logistics mode. When logistics mode not only should consider the factors of its influence, but also should be some uncertain factors in the future there may be included, so as to achieve scientific and comprehensive.

(2) combine the quantitative analysis with the qualitative analysis is applied to the study of the physical model. The quantitative analysis is a commonly used analysis method can make accurate analysis but sometimes due to practical constraints is not easy to achieve; the method of qualitative analysis and because the sovereignty assignment contains so many subjective factors. The ability of reaction situation is relatively poor point. AHP method of quantitative analysis and qualitative analysis in quantitative rivers in order to uncertain analysis, which makes the analysis more scientific and reasonable.

(3) we need to learn how to combine the management with some complex mathematical models, we can make sure that the rationality of the research and the correctness of the results.

\section{References}

[1] Wei Liu Wenshun Li,Wendy Huang.Analysis of the dynamic relation between logistics development and GDP growth in China. (2013).

[2] Deng Mingran.Wang Hua. A government guarantee system of logistics development in China. 2014. 
[3] Goh.M.Ling.C Logistics development in China. 2013.

[4] Rayong,H.F, Qing. Comparative analysis of logistics outsourcing and self operated Logistics_ — A new Supermarket Co., Ltd. as an example[J]. Logistics technology,2007,(5).

[5] H.W. Zhao . Logistics outsourcing-Tobacco business logistics[J]. Journal of Guizhou University of Technology ,2008,(5).

[6] A.F.Yuan.Game analysis of logistics outsourcing and logistics enterprises[J]. Chinese Market,2008,(10).

[7] T. Yi, X.Q. Hong, Li. The construction of enterprise logistics outsourcing risk early warning index system and outsourcing risk analysis and evaluation[J]. Logistics technology,2008,(9). 